\title{
Bank Regulation: One Size Does Not Fit All
}

\author{
David Grossmann $^{1}$ and Peter Scholz ${ }^{2}$
}

\begin{abstract}
Bank business models show diverse risk characteristics, but these differences are not sufficiently considered in Pillar 1 of the regulatory framework. Even if the business model is analyzed within the European SREP, global Pillar 2 approaches differ and could lead to competitive disadvantages. Using the framework of Miles et al. [1], we examine a dataset of 115 European banks, which is split into retail, wholesale, and trading banks. We show that shifts in funding structure affect business models differently. Consequently, a "one size" approach in Pillar 1 for the regulation of banks does not fit all.
\end{abstract}

JEL classification numbers: G21, G28, G32

Keywords: Bank Business Models, Bank Capital Requirements, Cost of Capital, Leverage Ratio, Regulation, SREP

\section{Introduction}

The Basel Committee on Banking Supervision (BCBS) establishes global standards for the regulation of all banks but neglects the individual attributes of business models for Pillar 1 requirements. The chosen business model, however, reflects the risk appetite of a bank and can be viewed as an additional indicator of emerging risks. So far, the risks of business models are only incorporated in Pillar 2 of the regulatory framework. Since 2015, the European supervisory review and evaluation process (SREP) evaluates the business model to cover risks that are not fully considered by Pillar 1 [2]. However, the Pillar 2 implementations vary internationally and the substantial analysis of business models is fairly new in Europe. Especially, since the results of the SREP may lead to additional capital requirements for different business models. In addition, the SREP of the EBA [2] does not consider the future non-risk sensitive leverage ratio and only affects European banks. The

${ }^{1} \mathrm{PhD}$ Student, Andrássy University Budapest, Hungary and HSBA Hamburg School of Business Administration, Germany. Corresponding author.

${ }^{2}$ Professor for Banking and Financial Markets, HSBA Hamburg School of Business Administration, Germany.

Article Info: Received: February 10, 2017. Revised : March 2, 2017.

Published online : September 1, 2017 
mentioned problems can lead to biases between business models because low-risk banks have to meet the same Pillar 1 requirements as high-risk banks, including the additional costs for the implementation. Furthermore, diverse international Pillar 2 interpretations can lead to competitive disadvantages between European and global banks, due to different capital requirements, or to regulatory arbitrage if headquarters are relocated to other regulatory jurisdictions. Based on this background, it seems to be necessary to consider business models in Pillar 1. Therefore, we analyze how bank business models react to higher capital requirements and shifts in funding structure.

The reasons to consider business models, in general, are diverse risk characteristics of banks [3] [4]. Existing and emerging risks of business models can include the underlying risk profile and risk appetite, strategic risks, poor financial performance, dependencies of the funding structure, or concentrations to certain customers and sectors [2]. Previous studies about bank business models focus on the profitability and operating costs [5], the probability of default [3], the impact of income and funding on the risk and return [6], or the performance and risk [4]. Building on that, we expand this field of research by examining the impact of additional capital requirements on different business models using the example of a non-risk sensitive capital ratio. We find that bank business models react differently to higher capital requirements, which illustrates once more the differences of the banking sector. If leverage decreases, the relative impact on the funding costs of retail banks is higher than for wholesale and trading banks. We conclude that bank business models should be considered in Pillar 1 of the regulatory framework to account for these differences. Furthermore, we suggest that capital requirements for non-risk sensitive capital ratios should be adjusted to the business model as well.

Our analysis is divided into two steps. In a first step, we define a procedure based on a study by Roengpitya et al. [5] to allocate 115 European banks into retail, wholesale, and trading bank business models. The distinction is based on funding structures and trading activities for each bank and for every year from 2000 to 2013. Since the European banking system is dominated by unlisted banks, a high share of unlisted banks is selected for the sample. In a second step, we examine exemplary shifts in the funding structure for each bank in the sample. The focus is on the "one size fits all" leverage ratio requirement of Pillar 1 because it can be seen as an equity ratio that limits the maximum leverage. An equity ratio seems to be the appropriate starting point to test impacts of additional capital requirements. For that reason, a methodology proposed by Admati et al. [7] and Miles et al. [1] is chosen. Miles et al. [1] use the method of the weighted average cost of capital (WACC) to test the impact of a potential doubling of Tier 1 capital on funding costs. We adapt the method into the "Weighted Average Cost of Regulatory Capital" (WAC(R)C) in order to address regulatory book capital only. Since the bank sample consists of unlisted banks, the positive link between the historical net return on Tier 1 capital and leverage is used as a proxy-model for the expected return. The statistical proxy-model can reflect the risk preferences of investors and is built on coefficient estimates from pooled ordinary least squares, fixed effects, and random effects regression models. Measurable differences in the regression coefficients of retail, wholesale, and trading bank business models are found. The regression coefficients are used to calculate the WAC(R)C and to compare the impacts of changing equity ratios. 


\section{Brief Literature Review}

We focus on a related field of research about the cost of higher capital requirements. After the financial crisis and the initial discussions about Basel III some argued that additional equity is expensive and would increase the funding costs for banks. ${ }^{3}$ In contrast, Admati et al. [7] argue that higher equity is not expensive because the risk premium in the return on equity decreases. They state that the benefits of better-capitalized banks reduce the likelihood of default. Admati et al. [7] base their statements on the propositions of Modigliani and Miller (M/M) [8]. They also refer to Miller [9] and Pfleiderer [10] for the use the of the M/M propositions on banks. The empirical test of the statements by Admati et al. [7] are provided by Miles et al. [1]. Miles et al. [1] test if higher equity ratios increase the cost of funding for a UK bank sample. Other empirical studies, which we refer to, find their origin in the work of Miles et al. [1]: the European Central Bank (ECB) [11], Junge et al. [12], Toader [13], Clark et al. [14], and Cline [15].

The comparative studies test to what extent shifts in funding structures affect the overall costs of banks. To determine the cost of equity for the WACC-method, the studies use the Capital Asset Pricing Model (CAPM) to estimate expected returns for listed banks. Miles et al. [1] examine the six largest banks in the UK and find an M/M offset of $45 \%-90 \%$ between 1997 and 2010. The M/M offset describes to what extent the WACC is independent of its capital structure and if bank's cost of capital increases once leverage changes. An M/M offset of $100 \%$ describes a total independence and approves the M/M propositions [1]. The ECB [11] tests 54 Global Systemically Important Banks (G-SIB) and finds an $\mathrm{M} / \mathrm{M}$ offset of 41\%-73\%. Junge et al. [12] find an $\mathrm{M} / \mathrm{M}$ offset of $36 \%-55 \%$ for Swiss banks. For large European banks, between 1997 and 2012 a 42\% M/M offset is found by Toader [13]. Clark et al. [14] examine 200 banks from the USA and find an M/M offset of $41 \%-100 \%$, which increases with the size of a bank. The hypothetical doubling of equity has a higher impact on the cost of capital for smaller banks than for the largest banks of their US sample. Last but not least, Cline [15] tests US banks and finds an M/M offset of $60 \%$.

The work of Admati et al. [7] and Miles et al. [1] offers an appropriate methodology for our research because it enables to examine the impacts of additional capital requirements on different bank business models. We expand the existing research about the cost of higher equity ratios with a focus on the European banking sector. In contrast to the use of the CAPM, we apply a proxy-model for the expected return because the sample is dominated by unlisted banks.

\section{Dataset}

The dataset for the sample is collected from the bankscope database Bureau van Dijk Electronic Publishing [16]. Additionally, for about $30 \%$ of the observations, further data on regulatory capital is collected from published disclosure reports based on $\$ 26 \mathrm{a}$ of the German Banking Act. The initial selection of the dataset is based on the balance sheet total by the end of 2013 for the biggest 90 banks in Germany and the 30 biggest banks in Europe. The majority of observations belong to German banks because of the availability of data

\footnotetext{
${ }^{3}$ Admati et al. [7] present several statements of bankers and researchers relating to this discussion.
} 
regarding Tier 1 capital. The sample includes both listed and unlisted banks with a majority of bank/year observations for unlisted banks $(63 \%)$. The dataset is an unbalanced panel that includes data from 2000-2013. Due to size and disclosure requirements of the banks, only yearly data is available for the full sample since semi-annual and quarterly reports are not published for more than half of the sample. The panel sample does not include data for all banks for every year, but we retain the banks in the analysis because they represent the financial system in Europe. The dataset is tested for banks with no observation for either the dependent or the independent variables, for data errors such as incorrect units, or for banks that are overtaken by competitors. Once an observed bank is under control of another European competitor for more than 50 percent of its shares the bank is dropped from the sample for the examined year. Due to the dataset, which is collected before Basel III is established, single components of the leverage ratio's exposure measure, e.g. off-balance sheet exposure, derivate exposure, and securities financing transaction exposure, are not available. As a consequence, lower ratios of leverage could be estimated due to missing off-balance sheet exposure. Hence, our results are solely based on published on-balance sheet exposure. The dataset also includes European G-SIB. Since all variables used for the models are measured in percentages, G-SIB's are not treated differently. The sample covers the timeframe after the Lehman Brothers bankruptcy. During the financial crisis, several banks received government support, e.g. guarantees or capital actions. The supportive actions of the European governments presumably saved the financial system. Nevertheless, government support can lead to a distortion of competition. Banks that received government support might have otherwise not survived and therefore, are not considered for the timeframe during which they received support to ensure comparability with banks not receiving governmental support. For robustness purposes, results for banks with government support are presented in footnote 5. The handling of banks with government support does not foster a possible survivorship bias. Quite the contrary, it increases the comparability among the remaining banks in the sample. Banks that failed and did not receive government support are included in the sample. Due to the availability of sufficient observations, we are not able to create comparable subsets regarding timeframes, e.g. pre and post crisis, within the time series. Approximately one-sixth of the observations is collected before 2007 as shown in Appendix II. The final sample includes 85 German and 30 European banks with 615 bank/year observations for both the dependent and the independent variables.

\section{Separation of the Banking Sector}

Our first step is to separate the dataset. The banking sector can be divided by several approaches such as the ownership structure, the liability system, the earning structure, or the bank business model [17]. In order to enable comparability with international banking sectors and to consider the riskiness of different business activities, we choose to differentiate the banks by the individual business model. Different methodologies to classify bank business models such as cluster analyses [3] [5], factor analyses [4], or a combination of ownership structures and business attributes [6] exist. Based on Roengpitya et al. [5], we define a procedure to separate the banking sample. The study is chosen because of the availability of the same database, operating figures, and utilized variables. Roengpitya et al. [5] distinguish bank business models solely by their business 
activities and funding structures ${ }^{4}$ and develop three business models: retail banks, wholesale banks, and trading banks. By definition, retail banks comprise collecting deposits from private and small corporate customers to deal in credits. Larger corporate customers, as well as financial institutions, are provided with banking services by wholesale banks. Retail and wholesale banks both have high shares of loans but differ in the type of refinancing. Retail banks use mainly customer deposits, whereas wholesale banks choose a broader funding structure [18] [5]. Koehler [6] finds that banks with a high share of deposit funding are more stable than non-deposit funded business models. By contrast, trading banks, which are also known as investment banks, focus on trading and investment activities with a predominantly market-based funding structure. They assist customers in raising equity and debt, consult on corporate finance decisions, and provide brokerage services [18] [5]. Overall, Ayadi et al. [2] discover that European retail business models resisted the financial crisis better and are less likely to default compared to wholesale and investment business models.

Roengpitya et al. [5] identify key and supportive ratios to differentiate between business models. These ratios include the share of loans (gross loans), the share of interbank liabilities (interbank borrowing), and the share of refinancing without customer and bank deposits (wholesale debt). Gross loans relate to the composition of the asset side, whereas interbank borrowing and wholesale debt relate to the funding structure of a bank. The procedure to allocate the banks in the sample is based on the key and supportive ratios. Furthermore, we add 'Derivative Exposure', and 'Trading Exposure' as additional ratios. In the first step, we look at banks with a high share of gross loans above 50 percent on the balance sheet as well as the corresponding funding structure. A retail bank is classified as a bank that depends largely on customer deposits ( $\geq 50 \%)$. In addition, a bank is classified as a retail bank if the share of gross loans is above $35 \%$, with the share of investment activities below $20 \%$, and if customer deposits exceed wholesale debt and interbank borrowing. Through this procedure, wholesale or trading banks characteristics are not dominating. If the refinancing through interbank borrowing (i.e. bank deposits) and wholesale debt (i.e. long-term liabilities, other deposits, and short-term bonds) exceed customer deposits, the bank is classified as a wholesale bank. In addition, a bank is classified as a wholesale bank if the share of gross loans is above $35 \%$, with a share of investment activities below $20 \%$, and if the interbank borrowing and wholesale debt exceed customer deposits. Through this procedure, retail or trading banks characteristics are not dominating. In the second step, we look at banks with a share of gross loans below 50 percent. Roengpitya et al. [5] find that trading banks hold approximately $20 \%$ of the balance sheet total in interbank related assets and liabilities (e.g. tradable securities). Therefore, banks whose trading activities (i.e. trade liabilities and derivative exposure) are above $20 \%$ are assigned to trading banks. In addition, banks whose share of interbank lending and trading activities exceeds the share of gross loans are classified as trading banks. As an exception, public development banks with high subsidies awarded to other banks are not classified as trading banks since they do not pursue trading activities. They are classified as wholesale banks. Every bank is classified for each year to allow for changes over time. Two bank/year observations could not be separated due to incomplete data regarding the

${ }^{4}$ It should be considered that information regarding the strategic plans, internal reporting, execution capabilities, or recovery and resolution plans as reviewed by the EBA [2] are not publicly available. The internal data could complement the classification of business models. 
asset structure. Both banks are assigned to retail banks because the business model did not change in the course of the timeframe.

Table 1: The Diversity of Bank Business Models.

\begin{tabular}{l|ccc|c}
\hline \multicolumn{1}{c|}{ Variables } & Retail & Wholesale & Trading & All Banks \\
\hline & & & & \\
Gross Loans & $63 \%(62 \%)$ & $51 \%(65 \%)$ & $29 \%(26 \%)$ & $52 \%(58 \%)$ \\
Interbank Borrowing & $14 \%(8 \%)$ & $26 \%(14 \%)$ & $23 \%(19 \%)$ & $20 \%(11 \%)$ \\
Wholesale Debt & $9 \%(11 \%)$ & $37 \%(37 \%)$ & $19 \%(18 \%)$ & $20 \%(19 \%)$ \\
Interbank Lending & $8 \%(9 \%)$ & $21 \%(8 \%)$ & $25 \%(22 \%)$ & $16 \%(11 \%)$ \\
Deposits & $65 \%(67 \%)$ & $26 \%(36 \%)$ & $28 \%(38 \%)$ & $46 \%(54 \%)$ \\
Stable Funding & $73 \%(74 \%)$ & $60 \%(63 \%)$ & $43 \%(49 \%)$ & $63 \%(67 \%)$ \\
Derivative Exposure & $0.2 \%(\mathrm{n} / \mathrm{a})$ & $5 \%(\mathrm{n} / \mathrm{a})$ & $18 \%(\mathrm{n} / \mathrm{a})$ & $6 \%(\mathrm{n} / \mathrm{a})$ \\
Trading Exposure & $0.1 \%(\mathrm{n} / \mathrm{a})$ & $2 \%(\mathrm{n} / \mathrm{a})$ & $15 \%(\mathrm{n} / \mathrm{a})$ & $4 \%(\mathrm{n} / \mathrm{a})$ \\
& & & & \\
\hline
\end{tabular}

Notes: Gross Loans: loans / total assets; Interbank Borrowing: deposits from banks / total assets; Wholesale Debt: other deposits plus short-term borrowing plus long-term funding / total assets; Interbank Lending: loans and advances to banks / total assets; Deposits: customer deposits / total assets; Stable Funding: total customer deposits plus long-term funding / total assets; Derivative Exposure: derivative / balance sheet; Trading Exposure: trading liabilities / total assets. Total assets are net of derivatives to avoid different balance sheet volumes through various accounting standards. Results of Roengpitya et al. [5] in parentheses.

The allocation of the sample matches predominantly the percentages of the comparative sample of Roengpitya et al. [5] as seen in parentheses in table 1. The chosen procedure to allocate the sample seems to be appropriate. The European sample shows a much higher share of interbank borrowing and interbank lending. The retail banks in the sample have above-average shares of gross loans and deposits and almost match the comparative sample. Wholesale banks in the sample have a smaller share of gross loans and a higher share of interbank lending compared to retail banks as well as the comparative sample. At the same time, wholesale banks account for the highest share of wholesale debt in our sample. Trading banks in the sample have the highest share of interbank lending as well as derivative and trading exposure. For the comparison of the results, it should be considered that not all data is available for the formulas 'interbank lending' and 'interbank borrowing'. Hence, 'reverse repurchase agreements and cash collateral', which could be added to the counter of the formulas, are not considered. Altogether, the sample consists of 302 retail bank observations, 193 wholesale bank observations, and 120 trading bank observations.

\section{Methodical Framework}

To test our hypothesis that higher equity ratios will raise funding costs for bank business models differently, we base our analysis on a methodology used by Miles et al. [1]. They 
empirically test the statements by Admati et al. [7] that are based on the capital structure theory of Franco Modigliani and Merton H. Miller. The M/M propositions state that the WACC of a company is independent of its capital structure because the return on equity will decrease once leverage is lowered. The cost for the higher share of equity will be offset due to a reduced financial risk spread on equity. Lower leverage makes equity less risky. At the same time, when the share of debt decreases, the required interest rate of debt will decrease as well because the probability of default will be reduced. Overall, the WACC remains unchanged [8]. The $\mathrm{M} / \mathrm{M}$ propositions assume perfect market conditions, such as no transaction costs and identical financing costs for private and corporate investors, but complicate the practical use. The $\mathrm{M} / \mathrm{M}$ propositions will not be used to increase bank's value, but to examine possible shifts in funding structure for different business models.

Our general methodology follows Miles et al. [1] and the above-mentioned studies, which have tested the M/M offset on listed banks in the UK, Europe, and the US. For more details on the comparative studies see Appendix I. In contrast, our focus is on a sample of listed and unlisted banks in Europe. Since the primary focus is on regulatory capital, we adapt the model of the WACC into the WAC(R)C for banks and concentrate on Tier 1 capital and the return on Tier 1 capital. The adaption is based on a WACC bank model designed by Heidorn et al. [19] which distinguishes between bank's equity components. However, the WAC(R)C is a more simplified model due to the available granularity of data regarding regulatory equity. The regulatory equity for a bank can be divided into Tier 1 and Tier 2 capital. Tier 1 capital is referred to as going-concern capital whereas Tier 2 capital is referred to as gone-concern capital. We use Tier 1 capital as equity only since other components of bank's equity such as hybrid capital or Tier 2 capital can be seen as debt regarding accounting standards and tax law. Tier 1 capital consists of Common Equity Tier 1 (CET1) and Additional Tier 1 capital and is the sum of common shares, stock surplus, retained earnings, and accumulated other comprehensive income as well as other disclosed reserves [20]. Miles et al. [1] refer to incomplete data regarding CET1 capital and use Tier 1 capital because they found a positive relationship between CET1 and Tier 1 capital. In addition, the leverage ratio formula of Basel III focuses on Tier 1 capital because non-Tier 1 capital components were seen less useful to absorb losses during the crisis [21]. The $\mathrm{WAC}(\mathrm{R}) \mathrm{C}$ is estimated as follows:

$W A C(R) C=\frac{\text { Tier } 1}{V} \cdot R_{\text {Tier } 1}+\frac{D}{V} \cdot R_{\text {Debt }} \cdot(1-t)$

where Tier 1 is the amount of banks' regulatory core capital, $V$ is the exposure measure of a bank, $D$ the amount of debt, Tier $1 / V$ the equity ratio, $D / V$ the debt ratio, and $t$ the corporate tax rate. As for the capital cost rates, $R_{\text {Tier } 1}$ is used as the return on Tier 1 capital and $R_{\text {Debt }}$ as the interest rate on debt capital.

The comparative studies, and we as well, use book values for Tier 1 because Tier 1 capital is available as a balance sheet value only. For the calculation of the expected return, the comparative studies use the capital-market-oriented CAPM. As an alternative, Miles et al. [1] suggest using realized earnings over the stock price as a proxy for the expected return. Since most European banks are not listed ${ }^{5}$, we use a proxy-model based on realized

${ }^{5}$ Exemplary for Germany: at the end of 2013 a total of 1,846 banks reported to the Deutsche Bundesbank [22]. Merely 19 of them were listed. 
historical returns for $R_{\text {Tier } 1}$. The use of historical returns follows the approach of the BCBS [21], which concentrates on historical earnings to develop risk sensitive capital ratios. As the desired proxy, the historical net return on Tier 1 capital and leverage are used. A positive relationship between the two variables is assumed because of to the $\mathrm{M} / \mathrm{M}$ propositions. Due to the use of book values, listed banks are treated as unlisted banks regarding the utilized variables. Our approach neglects the CAPM due to the underlying perfect market assumptions as well as the missing empirical prove of the model [23]. Using realized returns on Tier 1 capital might differ from previously calculated expected returns on equity and limits the comparability towards the CAPM. However, the advantage of the proxy-model is that we do not rely on peer group betas or other benchmark betas that do not distinguish between bank business models. The statistical proxy-model does not calculate the risk premium, but the coefficients of the model can reflect the risk preferences of investors [24].

\section{The Proxy-Model}

For the return-proxy, we use a panel regression approach. We need to assume that the average realized return on equity is close to the actual cost of equity. The regression models are based on log regressions due to skewed distributions of the variables. The regression is estimated as follows:

$\ln \left(R_{\text {Tier } 1_{i, t}}+1\right)=a+b \cdot \ln \left(\right.$ Leverage $\left._{i, t}\right)+c_{i, t}+z_{t}+\varepsilon_{i, t}$

where $i=1$ to $\mathrm{N}$ is the individual bank and $t=1$ to $\mathrm{T}$ is the time index. We use $a$ as a constant, $b$ as the coefficient of leverage, and $c$ as a control variable for additional explanatory bank-specific effects. Further, $z$ is used for time-specific effects (e.g. time dummies) and epsilon $(\varepsilon)$ is used as the error term for the non-systematic part of the regression model [25] [26].

The historical return on Tier 1 capital after taxes $\left(R_{\text {Tier } 1}\right)$ is used as the dependent variable. We choose the net return since dividends on shares are paid to investors after the company has paid corporate taxes. However, with the use of historical returns, years with financial losses are also included in the dataset. This is a mathematical problem since negative numbers cannot be logarithmized. There are various possibilities to deal with negative returns: the data could be trimmed, winsorized, swapped, or a constant could be added. Trimming or winsorizing data can reduce extreme values, but could lead to a misinterpretation of the results. Cline [15] suggests to swap negative returns for a minimum expected return of a five year treasury bond plus a risk spread. Another option is to swap the negative returns for the average return of the time series. Swapping generates a minimum expected return for investors, who might otherwise not invest if the bank is expected to generate a loss. However, this assumption might only work for a short investment-period because investments with negative expected returns can turn into positive expected returns in the long run. We decided to keep the negative returns and add a constant of 1 to all returns since equity is a risky asset, which generates positive and negative returns. The adding of a constant $\ln \left(R_{\text {Tier } 1_{i, t}}+1\right)$ enables us to logarithmize the variables.

Leverage as the independent variable is measured as total assets divided by Tier 1 capital. We decide to use on-balance sheet exposure only because off-balance sheet data is not 
available for every bank in our sample. Because of changes in the definition of Tier 1 capital during Basel I to III and the lack of adjusted Tier 1 capital figures during the observed timeframe, the ratios of leverage might not be entirely comparable to each other. This should be considered when the results are interpreted. It is challenging to control for the impact of bank-specific effects over time. The effects of changes in risks of assets can be assessed through control variables that reflect the overall situation of the individual bank such as the profitability, the liquidity situation, potential losses, or size [1]. For the explanatory bank-specific control variables, we follow Miles et al. [1] and use the return on assets (ROA), a liquid asset ratio (LAR), and a loan loss reserve ratio (LLRR). The ROA is measured as net income divided by total assets and reviews the profitability of the total assets of a bank. The LAR is computed as liquid assets divided by total liabilities minus Tier 1 equity and stands for the capability to sell assets without high losses. The LLRR is calculated as the total loan loss reserves divided by total assets and checks for the probability of potential future losses due to loan defaults. In addition, the size of a bank (logarithm of total assets) as suggested by the ECB [11] is used. Further, to cover the impact on the average riskiness of assets from year to year, such as a general economic boom [11], additional time dummies are added to the regression model.

\section{Statistics and Results}

We aim to find a robust regression model to use the coefficients of the proxy-model to calculate the return on Tier 1 capital for the $\mathrm{WAC}(\mathrm{R}) \mathrm{C}$. For that reason, four regression models are used: one baseline model and three extended panel regression models. The models are based on pooled ordinary least squares (OLS), fixed effects (FE), and random effects (RE) regression methods. The extended models consider additional control variables to test for bank-specific effects as well as annual time dummies. Subsequently, the individual models are statistically tested against each other. The procedure is based on the procedure of the comparative studies.

The descriptive statistics for the utilized dependent and independent variables are presented in Appendix III. The variables show some extreme minimum and maximum values (e.g. outliers) that might have an influence on the regression models. Extreme values are not trimmed nor winsorized to reveal the actual banking sector. It should be noted, that the financial crisis, as well as the regulatory driven build-up of Tier 1 capital, are also covered in the dataset. The majority of bank/year observations with about $49 \%$ belong to retail banks. The remaining observations are split with approximately $31 \%$ to wholesale and with approximately $20 \%$ to trading banks. The average leverage for the sample is 26.19 for the observed timeframe. Retail banks have an average leverage of 18.65, while wholesale (29.59) and trading (39.69) banks account for a higher leverage. With a lower leverage, retail banks seem to be less risky. Trading banks display a comparatively high standard deviation due to the retained outliers. Without five extreme outliers that display leverage above 100, the average leverage for trading banks would account for approximately 36.13. The average return on Tier 1 capital for the sample is $8.50 \%$. Trading banks account for the highest realized net return on Tier 1 capital with an average of $9.40 \%$ compared to retail $(9.01 \%)$ and wholesale banks $(7.10 \%)$. The descriptive statistics indicate that leverage might have an impact on the return on Tier 1 capital. The sample with the highest leverage claims the highest return. 
Model 1 - Baseline

Starting with a fixed effect baseline regression, as shown in table 2, a positive link between the net return on Tier 1 capital and leverage can be found for all samples. Hence, a higher return on equity can be connected to higher levels of debt. The link is statistically significant (p-value 0.070) for the whole bank sample. If the confidence level is changed to $88 \%$, a statistically significant relationship can also be found for retail banks ( $\mathrm{p}$-value 0.122 ) and trading banks (p-value 0.119). For retail banks, positive significant coefficients are also found for a baseline regression model based on ordinary least squares $\left(0.031^{* *}\right)$ and random effects $(0.044 * *)$. Wholesale banks display a positive relationship, but a statistically significant relationship cannot be found for the number of observations. A fourth sample consisting of the wholesale and trading bank samples (W+T) is added for a better comparability with the retail bank sample regarding the number of observations. A positive relationship for $\mathrm{W}+\mathrm{T}$ is found but the link does not seem to be statistically significant mostly due to the wholesale bank observations.

Table 2: Baseline Regression.

\begin{tabular}{lccccc}
\hline \multicolumn{1}{c}{$\boldsymbol{F E}$ - Baseline } & All Banks & Retail & Wholesale & Trading & W + T \\
\hline Coef. Leverage & $0.040^{\prime}$ & 0.041 & 0.005 & 0.081 & 0.027 \\
Std. Error & 0.022 & 0.026 & 0.041 & 0.052 & 0.033 \\
Adjusted R & 0.005 & 0.008 & 0.000 & 0.020 & 0.002 \\
F-Test (p-value) & 0.070 & 0.122 & 0.905 & 0.119 & 0.418 \\
Observations & 615 & 302 & 193 & 120 & 313
\end{tabular}

Notes: The dependent variable is the log of the return on Tier 1 capital after taxes since dividends are paid after corporate taxes. The independent variable is log leverage. The null-hypothesis of the Breusch-Pagan test is rejected for all models, which indicates heteroskedasticity. A Breusch-Godfrey/Wooldridge [25] test indicates autocorrelation in residuals for all banks and retail banks. The wholesale and trading banks sample cannot reject the null hypothesis.

Level of significance: $* * * p<0.001, * * p<0.01, * p<0.05,{ }^{\prime} p<0.10$.

\section{Control Variables}

The following three models are calculated with control variables. As mentioned above, the selection of control variables is based on the comparative studies. It should be noted, that our approach differs from the comparative studies in the use of unlisted banks and the derivation for the rates of return. The majority of the comparative studies regress leverage and the control variables on the equity beta of a listed bank, which supposedly reflects the equity risk of the bank [1]. In the CAPM, the equity beta has a strong, although indirect, influence on the expected return on equity. In contrast, we regress the independent variables directly on the return on Tier 1 capital. The explanatory bank-specific control variables show diverse impacts. The coefficients for ROA indicate a strong positive link to the net return on Tier 1 capital for all samples. Appendix IV shows that ROA has a strong impact on the adjusted R-squared when added to the regression models. It seems reasonable that the return on total assets has a positive influence. However, ROA cannot be attributed to 
regulatory equity as a whole. The positive correlation ${ }^{6}$ of 0.732 between the net return on Tier 1 capital and ROA indicates that other components of bank's equity or debt, regarding accounting standards and tax law, benefit from ROA. Hence, ROA could be split into components that belong to Tier 1 capital and into components that can be attributed to hybrid capital (e.g. loss-absorbing debt) or other accounting equity components that are not regulatory Tier 1 capital. Therefore, we decide to keep ROA as a control variable. The coefficients for LAR in the OLS regressions have a positive link for the all banks samples and are statistically significant for the FE and RE models. The liquidity situation seems to have a positive impact on the return on Tier 1 capital. However, for the retail, wholesale, and trading bank subsamples, the LAR indicates a positive link in most cases but is not significant for the FE and RE models. The LLRR does not seem to have an influence on the dependent variable as no significant links can be found. The total assets variable does not produce robust results either. For more than half of the models tested, the influence is negative, albeit not statistically significant. The size of the bank only seems to have a minor influence on the return on regulatory capital of retail banks in the RE model, but not for the all banks, wholesale, and trading banks samples. The results surprise because the ECB [11] finds a robust relationship. One possible explanation could be the selection of mostly unlisted banks. Overall, we decide to drop LLRR and total assets as control variables from all regressions because they do not show an impact on the regression models. The different impacts can be seen in Appendix IV with an overview of all variables for the fixed effects regression models. We also check for the Gauss-Markov assumptions for the regression models [26]. All variables cannot reject the null-hypotheses of the Jarque-Bera test for normal distribution.

\section{Model 2 - OLS}

When using the remaining independent variables for the OLS regressions, as shown in table 3, we find positive significant relationships for the all bank, retail bank, and wholesale bank samples. A negative, albeit not significant link for trading banks is found. In addition, the combined sample of wholesale and trading banks shows a positive, but not statistically significant link.

${ }^{6} \mathrm{~A}$ Kendall's tau test for variables that are not normally distributed is used to measure the correlation. As a comparison, the correlations between the net return on Tier 1 capital and: leverage is 0.460 ; LAR is 0.668 ; total assets is 0.146 ; and LLRR is -0.094 . 
Table 3: Ordinary Least Squares (OLS) Regression.

\begin{tabular}{lccccc}
\hline \multicolumn{1}{c}{ OLS } & All Banks & Retail & Wholesale & Trading & W + T \\
\hline Coef. Leverage & & & & & \\
Std. Error & $0.039^{* * *}$ & $0.076^{* * *}$ & $0.029^{*}$ & -0.008 & 0.013 \\
Constant & 0.006 & 0.007 & 0.012 & 0.014 & 0.009 \\
ROA & $-0.098^{* * *}$ & $-0.225^{* * *}$ & -0.053 & -0.017 & -0.023 \\
LAR & $20.382^{* * *}$ & $17.434^{* * *}$ & $24.004^{* * *}$ & $26.729^{* * *}$ & $24.387^{* * *}$ \\
Adjusted R & 0.004 & -0.000 & $0.011^{\prime}$ & $-0.024^{\prime}$ & $0.010^{\prime}$ \\
F-Test (p-value) & 0.768 & 0.828 & 0.790 & 0.676 & 0.767 \\
Observations & 0.000 & 0.000 & 0.000 & 0.000 & 0.000 \\
Year Effects & 610 & 297 & 193 & 120 & 313 \\
& Yes & Yes & Yes & Yes & Yes \\
\hline
\end{tabular}

Notes: The dependent variable is the log of the net return on Tier 1 capital. The independent variables are log leverage, log return on assets, log liquid asset ratio as well as year dummies. Annual time dummies are not shown. The null hypotheses of the Breusch-Pagan test can be rejected for all models except for trading banks. A BreuschGodfrey/Wooldridge [25] test indicates serial correlation in residuals for all models. Level of significance: $* * * p<0.001, * * p<0.01, * p<0.05,{ }^{\prime} p<0.10$.

Model $3-\mathrm{FE}$

The FE model can account for bank-specific, unobserved effects and allows the unobserved effects to be correlated with the independent variables in each time period. For the within models in table 4, statistically significant relationships for all banks, retail banks, trading banks, and the combined $\mathrm{W}+\mathrm{T}$ sample are found. As for wholesale banks, we find a positive link, but the model does not seem to be statistically significant. ${ }^{7}$

\footnotetext{
${ }^{7}$ As a robustness check, the FE regression models are calculated including banks that received government support during the financial crisis. The tendencies of the results are similar with positive leverage coefficients for all banks $\left(0.038^{* *}\right)$, retail banks $\left(0.078^{* * *}\right)$, trading banks $(0.064 *)$, and the combined $\mathrm{W}+\mathrm{T}$ sample (0.007).
} 
Table 4: Fixed Effects (FE) Regression.

\begin{tabular}{lccccc}
\hline \multicolumn{1}{c}{$\boldsymbol{F E}$} & All Banks & Retail & Wholesale & Trading & W + T \\
\hline Coef. Leverage & $0.066^{* * *}$ & $0.076^{* * * *}$ & 0.025 & $0.122^{* *}$ & $0.047 *$ \\
Std. Error & 0.020 & 0.021 & 0.017 & 0.044 & 0.019 \\
ROA & $24.011^{* * *}$ & $18.401 * * *$ & $27.121^{* * *}$ & $38.349 * * *$ & $29.349 * * *$ \\
LAR & $0.014^{*}$ & 0.005 & 0.008 & 0.010 & 0.015 \\
Adjusted R & 0.642 & 0.626 & 0.631 & 0.531 & 0.637 \\
F-Test (p-value) & 0.000 & 0.000 & 0.000 & 0.000 & 0.000 \\
Observations & 610 & 297 & 193 & 120 & 313 \\
Year Effects & Yes & Yes & Yes & Yes & Yes \\
& & & & &
\end{tabular}

Notes: The dependent variable is log return on Tier 1 capital after taxes. The independent variables are log leverage, log return on assets, log liquid asset ratio and year dummies. Annual time dummies are not shown. The results for the FE within models are computed by one-way (individual) effects. Consistent standard errors are used to address for heteroskedasticity.

Level of significance: $* * * p<0.001, * * p<0.01, * p<0.05,{ }^{\prime} p<0.10$.

For the FE models, the null-hypotheses for the Breusch-Godfrey/Wooldridge [25] test that there is no serial autocorrelation cannot be rejected. Further, the null-hypotheses of the Breusch-Pagan test can be rejected, which indicates heteroskedasticity for the FE models except for the trading bank sample. For that reason, robust covariance matrix estimators by Arellano [27] for the FE and RE models for the unbalanced panel dataset are chosen. The Arellano estimator permits heteroskedasticity and serial correlation. ${ }^{8}$

\section{Model $4-$ RE}

The RE model can also account for bank-specific, unobserved effects, but assumes that the unobserved effects are uncorrelated with the independent variables in all time periods. The last of the panel regression models is the RE model. We test for the empirical relationship of leverage on the return on Tier 1 capital and assume that unobserved effects are uncorrelated with the independent variables.

${ }^{8}$ Robust standard errors by Driscoll and Kraay [28] are not used because the timeframe is shorter than the recommended minimum timeframe of 20 to 25 years. Instead, the vcovHC function with the Arellano estimator in ' $\mathrm{R}$ ' as offered by Croissant and Millo [29] is used. 
Table 5: Random Effects (RE) Regression.

\begin{tabular}{lccccc}
\hline \multicolumn{1}{c}{$\boldsymbol{R} \boldsymbol{E}$} & All Banks & Retail & Wholesale & Trading & W + T \\
\hline Coef. Leverage & $0.041^{* * *}$ & $0.074 * * *$ & $0.028^{\prime}$ & -0.003 & $0.019^{\prime}$ \\
Std. Error & 0.015 & 0.017 & 0.015 & 0.029 & 0.020 \\
Constant & $-0.128^{* * *}$ & $-0.197 * * *$ & -0.071 & -0.043 & -0.074 \\
ROA & $22.114^{* * *}$ & $17.885 * * *$ & $25.531^{* * *}$ & $28.313 * * *$ & $26.232^{* * *}$ \\
LAR & $0.006^{*}$ & 0.002 & 0.010 & -0.020 & 0.008 \\
Adjusted R & 0.779 & 0.821 & 0.796 & 0.677 & 0.781 \\
F-Test (p-value) & 0.000 & 0.000 & 0.000 & 0.000 & 0.000 \\
Observations & 610 & 297 & 193 & 120 & 313 \\
Year Effects & Yes & Yes & Yes & Yes & Yes \\
& & & & &
\end{tabular}

Notes: The dependent variable is the log of the return on Tier 1 capital after taxes. The independent variables are log leverage, log return on assets, log liquid asset ratio, and annual time dummies. Yearly time dummies are not shown. The results for the RE models are computed by one-way (individual) effects. Consistent standard errors based on Arellano [27] are used to address for heteroskedasticity and serial correlation. Level of significance: $* * * p<0.001, * * p<0.01, * p<0.05,{ }^{\prime} p<0.10$.

For the RE models in table 5, statistically significant links for all banks, retail banks, wholesale banks, and the combined W+T sample are estimated. As for the trading banks, a significant link cannot be found. A serial correlation in residuals for the RE models is found as the null-hypotheses of the Breusch-Godfrey/Wooldridge [25] test can be rejected for all samples. A Breusch-Pagan test indicates heteroskedasticity for all samples except for the trading banks.

\section{Selection of Model}

Overall, the results of the three panel regression models show positive relationships between the dependent and independent variables. After estimating the models with additional control variables, we use statistical tests to choose between the different regressions models as described by Wooldridge [26]. First, the OLS and the FE models are compared. We choose the FE models over the OLS models because the null-hypotheses for the F-test, which indicates no individual unobserved effects, can be rejected for all banks (p-value 0.000), retail banks (p-value 0.000), wholesale banks (p-value 0.000), trading banks (p-value 0.000), and the combined W+T sample (p-value 0.000). Secondly, the OLS and the RE regression models are compared. We use a Lagrange Multiplier Test for panel models computed by Breusch-Pagan. If the null-hypothesis can be rejected, the RE model is better. We find that the RE models seem to be more appropriate than the OLS for all samples. Thirdly, both the FE and RE models seem to be consistent. Compared to the within models, the RE models have higher explanatory values for the adjusted R-squared. To decide which model to use, we test for statistically significant differences in the coefficient of the time-varying independent variables for the FE and RE models by using a Hausman test [26]. The null-hypothesis means that the differences in the coefficients are not 
significant and that unobserved variables are not correlated with the independent variables. The Hausman test indicates that the FE model can be used for retail banks (p-value 0.000), trading banks (p-value 0.000), and the combined $\mathrm{W}+\mathrm{T}$ sample (p-value 0.000). The RE model seems better for all banks (p-value 0.150) and wholesale banks ( $p$-value 0.347). Overall, we choose the FE over the RE models because it allows a comparison between the retail banks and combined $\mathrm{W}+\mathrm{T}$ sample with almost identical numbers of observations. An alternative method could be to use both the FE and RE models for the calculations, but the comparison of the results might be biased. By choosing the FE model the unobserved effects can be correlated with the independent variables. Overall, we choose the baseline regressions and the FE estimates for the proxy-model to calculate the return of Tier 1 capital for the WAC $(\mathrm{R}) \mathrm{C}$.

The results seem to be in line with the referred study of Miles et al. [1], who find a positive coefficient for leverage for the six largest UK banks of 0.031 for an FE model. The ECB [11] observes international G-SIB and finds a positive leverage coefficient for the FE model of 0.079. Clark et al. [14] find a positive coefficient of 0.062 for an FE model for the largest US banks between 2007 and 2012. Furthermore, Toader [13] estimates an FE coefficient of 0.026 for 85 European listed banks. In spite of the similarities, it is important to mention that the results are not directly comparable due to the underlying assumptions, e.g. the use of control variables, the use of the CAPM with expected return assumptions, and the proxymodel based on actual realized returns.

\section{Calculating the WAC $(\mathrm{R}) \mathrm{C}$}

The regression estimates for the proxy-model show that an increase of leverage can be connected to a higher net return on Tier 1 capital with measurable differences between bank business models for the European sample. We follow Miles et al. [1] and use two exemplary illustrations for the calculation of the WAC $(\mathrm{R}) \mathrm{C}$. Two identical equity ratios for all bank business models of $3 \%$ and $6 \%$ (leverage of 33.33 and 16.67) are used. This assumption might not represent the reality because the leverage of the all whole bank sample is lower and only the trading bank sample has a higher leverage. The BCBS leverage ratio of $3 \%$ is a minimum requirement that most banks in the sample exceed. However, the hypothetical assumption enables us to test if bank business models react differently to shifts in funding structure. For robustness purposes, the actual leverage for all samples is used as well. We use the coefficients of the regression models to calculate $R_{\text {Tier } 1}$ for the above described formula (1) of the WAC $(\mathrm{R}) \mathrm{C}$. The return on Tier 1 capital can be calculated by inserting the coefficient of leverage into the proxy-model:

$\exp (a+b \cdot \ln ($ Leverage $))=R_{\text {Tier } 1}$

with $a$ as the constant and $b$ as the coefficient of leverage. For the calculation of formula (3) two aspects have to be considered. One, the fixed effects models do not report intercepts for the regression outcomes. Therefore, we assume zero as the intercept. This enables an equal basis for the regression lines. An alternative method could be the average of the fixed effects for the individual banks of the FE regressions. However, this would not be an intercept in a classical meaning because it would be the average of the unobserved variable across time [25]. Second, for the results of $R_{\text {Tier } 1}$ the previously added constant of 1 to handle negative returns is subtracted after the calculation of formula (3). Overall, the net 
return on Tier 1 capital for the all bank sample in the baseline model with an equity ratio of $3 \%$ is $15.06 \%$. The rate is comparable to the return on equity of $14.85 \%$ that Miles et al. [1] calculate for their (baseline) model. ${ }^{9}$

For the debt part of the WAC(R)C formula, the comparative studies use a constant debt rate regardless of the debt structure, which is a simplification and overlooks the possible impact of leverage on the actual cost of debt. The assumption follows the idea that debt (e.g. savings deposits) can be seen as risk-free due to deposit insurance and implicit state guarantees. The probability of default for debt can still be measured, but the value of riskfree debt is not correlated with general market movements [14]. If non-constant debt rates are assumed for the WAC $(\mathrm{R}) \mathrm{C}$, the probability of default could be measured by exploiting credit ratings for different bank business models. However, both the German Savings Banks and Giro Association with about 600 members as well as the German Cooperative Financial Network with about 1000 members have group ratings for all members due to the ownership based liability system. Banks within one liability system might have different rating grades if the ratings were based on the individual bank business model. However, individual-based rating grades do not exist for the majority of banks in the sample. Additionally, G-SIB can have lower funding costs than non-systemically important banks due to an expected state support [30], which affects the comparability. Given the described obstacles, we follow the simplification of the comparative studies and assume a constant risk-free debt rate. This assumption reduces the M/M effect on debt for the bank sample. Miles et al. [1] choose a debt rate of 5\%, which is the approximately average bank rate between 1999 and 2009. In contrast, Junge et al. [12] use a constant rate of debt of $1 \%$. The $1 \%$ debt rate seems to be in line with market conditions since the end of 2011 when the yield of German treasury bonds with a maturity of five years fell below $1 \%$ or since 2009 (and again 2011) when the ECB set the interest rate for main refinancing operations at $1 \%$ [31]. We use 5\% for the debt rate, but also present calculations with $1 \%$. As for the corporate tax rate a flat rate of $35 \%$ is used for the calculations.

For the baseline calculation as presented in table 6 , the $\mathrm{WAC}(\mathrm{R}) \mathrm{C}$ for the whole bank sample accounts for $3.604 \%{ }^{10}$. The hypothetical doubling of equity for the illustrative calculations would reduce the return on Tier 1 capital to $11.91 \%$ and increase the WAC(R)C by 16.6 basis points to $3.770 \%$. If we assume that the $\mathrm{M} / \mathrm{M}$ propositions would not hold at all, investors would expect the same return on equity regardless of leverage. Therefore, the WAC(R)C would increase by 35.4 basis points to $3.958 \%$ (i.e. $6 \% \cdot 15.06 \%+94 \% \cdot 5 \%$. $(1-35 \%))$. If the M/M effect would not be present, the WAC(R)C would rise about $47 \%$ (16.6 bps./35.4 bps.). Conversely, the M/M offset is about $53 \%$ for all banks of the sample. ${ }^{11}$

${ }^{9}$ If using the average of the fixed effects as the intercept, the return on Tier 1 capital would account for $9.03 \%$ for the all bank sample, $11.69 \%$ for retail banks, and $7.37 \%$ for the $\mathrm{W}+\mathrm{T}$ sample. The relative impact on the $\mathrm{WAC}(\mathrm{R}) \mathrm{C}$ would be approximately $1.75 \%$ higher for retail banks compared to the $\mathrm{W}+\mathrm{T}$ sample.

${ }^{10}$ Calculation: equity ratio $(3 \%) \cdot R_{\text {Tier } 1}(15.06 \%)+$ debt ratio $(97 \%) \cdot R_{\text {Debt }}(5 \%) \cdot(1-$ tax rate $35 \%)$ ).

${ }^{11} \mathrm{An} \mathrm{M} / \mathrm{M}$ offset of $100 \%$ describes a total independence of the cost of capital on capital structure. 
Table 6: Cost of Capital - Baseline.

\begin{tabular}{lccc}
\hline \multicolumn{1}{c}{ Cost of Capital - Baseline } & All Banks & Retail & W+T \\
\hline & & & \\
Coefficient Leverage & 0.040 & 0.041 & 0.027 \\
$R_{\text {Tier 1 for 3\% Equity Ratio }}$ & $15.058 \%$ & $15.462 \%$ & $9.930 \%$ \\
WAC(R)C with 3\% Equity Ratio & $3.604 \%$ & $3.616 \%$ & $3.450 \%$ \\
$R_{\text {Tier 1 for 6\% Equity Ratio }}$ & $11.911 \%$ & $12.227 \%$ & $7.892 \%$ \\
WAC(R)C with 6\% Equity Ratio & $3.770 \%$ & $3.789 \%$ & $3.529 \%$ \\
$\Delta$ Impact on Cost of Capital & 0.166 & 0.173 & 0.079 \\
Relative Impact & $\mathbf{4 . 6 1 \%}$ & $\mathbf{4 . 7 8 \%}$ & $\mathbf{2 . 2 9 \%}$ \\
M/M Offset & $53 \%$ & $53 \%$ & $61 \%$ \\
& & & \\
\hline
\end{tabular}

Notes: The constants and coefficients are withdrawn from table 2. The return on Tier 1 capital is based on the proxy-model. WAC $(R) C$ is measured with an interest rate for debt of 5\% (risk-free debt) and a corporate tax rate of 35\%. The delta shows the impact of increased capital requirements on the overall funding costs in basis points. The $M / M$ offset describes to what part the WAC $R) C$ is independent of the capital structure.

It is assumed that higher equity ratios will reduce the risk of banks. This assumption can be measured for the return on Tier 1 capital as it will drop for retail banks from $15.462 \%$ to $12.227 \%$ and for the combined $\mathrm{W}+\mathrm{T}$ sample from $9.930 \%$ to $7.892 \%$. When comparing the relative impacts of decreased leverage, we find that the WAC(R)C of retail banks rises by $4.78 \%$ compared to $2.29 \%$ for the combined sample. If taxes are neglected [1] [11] [14] the relative impact for retail banks would drop to $2.25 \%$ compared to $0.50 \%$ for wholesale and trading banks. If the interest rate for debt is changed to $1 \%$ and taxes are neglected [12] the relative impact for retail banks would account for $16.72 \%$ compared to $11.48 \%$ for wholesale and trading banks. ${ }^{12}$

\footnotetext{
${ }^{12} \mathrm{Based}$ on actual data, retail banks disclose an average leverage of 18.65 compared to wholesale and trading banks with a combined leverage of 29.74. If the calculation of the $\mathrm{WAC}(\mathrm{R}) \mathrm{C}$ is based on the actual levels of leverage the relative impact is $2.69 \%$ for retail banks and $2.01 \%$ for the combined $\mathrm{W}+\mathrm{T}$ sample.
} 
Table 7: Cost of Capital - Extended

\begin{tabular}{lccc}
\hline \multicolumn{1}{c}{ Cost of Capital - Baseline } & All Banks & Retail & W+T \\
\hline & & \\
Coefficient Leverage & 0.066 & 0.076 & 0.047 \\
$R_{\text {Tier 1 for 3\% Equity Ratio }}$ & $26.040 \%$ & $30.539 \%$ & $17.917 \%$ \\
WAC(R)C with 3\% Equity Ratio & $3.934 \%$ & $4.069 \%$ & $3.690 \%$ \\
$R_{\text {Tier 1 for 6\% Equity Ratio }}$ & $20.404 \%$ & $23.840 \%$ & $14.137 \%$ \\
WAC(R)C with 6\% Equity Ratio & $4.279 \%$ & $4.485 \%$ & $3.903 \%$ \\
$\Delta$ Impact on Cost of Capital & 0.345 & 0.416 & 0.213 \\
Relative Impact & $\mathbf{8 . 7 7 \%}$ & $\mathbf{1 0 . 2 2 \%}$ & $\mathbf{5 . 7 7 \%}$ \\
M/M Offset & $49 \%$ & $49 \%$ & $52 \%$ \\
& & \\
& & \\
\hline & Notes: The constants and coefficients are withdrawn from table 4. WAC $(R) C$ is \\
measured with an interest rate for debt of 5\% (risk-free debt) and a corporate tax rate \\
of 35\%. The impact of higher capital ratios on the cost of regulatory capital are shown \\
in basis points by the delta. The M/M offset describes to what part the WAC $(R) C$ is \\
independent of the capital structure when the amount of equity is doubled.
\end{tabular}

In the extended models, the relative impact on the cost of capital for the combined wholesale and trading sample $(5.77 \%)$ is lower than for retail banks $(10.22 \%) .{ }^{13}$ It can be seen that the M/M offset is higher for the $\mathrm{W}+\mathrm{T}$ sample $(52 \%)$ than for retail banks $(49 \%)$. Both indicate a partly dependence of the funding costs on bank's capital structure. If the $\mathrm{M} / \mathrm{M}$ propositions completely hold, the $\mathrm{WAC}(\mathrm{R}) \mathrm{C}$ would not change if leverage decreases and the relative impact would tend toward zero. The smaller the relative impact, the higher the irrelevance of capital structure. At first sight, the returns on Tier 1 capital seem to be high, particularly when compared to the baseline model. Though, it seems realistic that a minimum equity ratio of $3 \%$, which barely fulfills the regulatory requirements, will call for a higher return. However, it surprises that the calculated cost of Tier 1 capital in both models is higher for retail banks than for the combined W+T sample. An explanation could be the chosen timeframe and the existing data for the time series. First, after the financial crisis, $70 \%$ of the observations with negative returns (i.e. losses) belong to wholesale and trading banks. With less negative returns retail banks seem to be the less risky business model. Second, the unbalanced panel dataset has an uneven distribution of observations regarding retail, wholesale, and trading banks before and after 2007 (see Appendix II). Further research could increase the number of observations. Nevertheless, the calculations are not meant to identify the actual cost of capital for banks but to show the impacts of shifts in funding structure.

\footnotetext{
${ }^{13}$ If the tax effect is neglected [1], the relative impact for retail banks (6.32\%) is twice as high as for the wholesale and trading bank sample (2.98\%).
} 

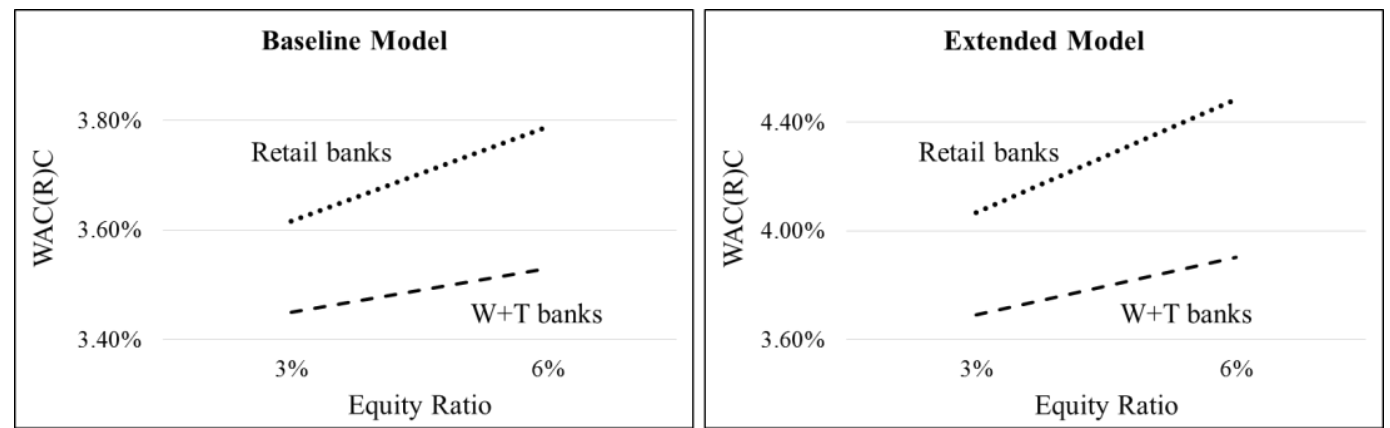

Notes: The figures show the WAC $(R) C$ s for an equity ratio of $3 \%$ and a potential doubling of equity to $6 \%$ for retail banks and the combined wholesale and trading $(W+T)$ bank sample. The WAC $R) C$ increases relatively more for retail banks, which can be seen in the slope of the line or in table 6 and 7. The relative impacts on the $W A C(R) C$ are smaller for the $W+T$ sample.

Figure 1: Unequal Impacts on the Cost of Regulatory Capital.

Overall, we can support the comparative studies surrounding Miles et al. [1] that the cost of capital is partly irrelevant regarding the capital structure of banks. A potential doubling of equity would raise the funding costs of European banks between 8 basis points in the baseline model to 42 basis points in the extended model, the tax-effect included. Higher capital requirements are not free but the amount seems to be acceptable to strengthen the financial system. The results for retail banks and the combined wholesale and trading bank sample vary in both the baseline and the extended calculations. Regardless of the assumptions for the proxy-model with historical returns, the different regression models, or the calculated parameters for the WAC $(\mathrm{R}) \mathrm{C}$, bank business models react differently to shifts in funding structure. Consequently, the differences of business models should also be considered for a non-risk sensitive equity ratio. A "one size" approach in Pillar 1 does not fit all.

\section{Conclusion}

The examination of bank's business model through Pillar 2 is fairly new in the European supervisory practice. Therefore, we analyze the impact of shifts in funding structure on bank business models by using the framework of Miles et al. [1] and the example of the non-risk sensitive leverage ratio. We find that the observed bank business models react differently to shifts in funding structure. The outcome that differences between banks exist may not surprise much. However, this raises the question why bank business models have not been considered before in Pillar 1 ?

The reasons for the observed differences are the business activities and the underlying funding structures. Both are based on the chosen strategy, the risk appetite, and risk-return profile of the business model. Deposits are the most important source of debt refinancing for retail banks. Wholesale and trading banks use a broader mix of debt capital. Hence, a retail bank with a high share of deposit funding needs different capital and liquidity requirements than a low-deposit funded wholesale or trading bank. The results support Ayadi et al. [3] and Mergaerts et al. [4] that the differences between business models should be considered in regulatory and supervisory practice. The diverse risk characteristics can be used as an additional indicator of emerging risks and require differentiated capital and 
liquidity requirements. Further, we can support Ayadi et al. [32] that a non-risk sensitive leverage ratio requirement should be adjusted to the risk profile of the individual bank business model. Future research could concentrate on developing different capital and liquidity requirements for bank business models.

The EBA has made the first step towards a differentiated regulation of banks. However, the implementation of the new European SREP differs to other global Pillar 2 approaches, which could lead to disadvantages or regulatory arbitrage. An internationally coordinated approach and a consistent implementation could prevent possible disadvantages. For this reason, the consideration of bank business models in Pillar 1 of the Basel framework is desirable.

ACKNOWLEDGEMENTS: We are grateful to Claudia Bott, Martina Eckardt, Giovanni Millo, Stefan Okruch, Stefan Schoenherr, Tillman van de Sand, Aline Taenzer, Ursula Walther, participants of the Claussen-Simon Graduate Centre at HSBA, and session participants of the 2016 "Merton H. Miller" doctoral seminar of the European Financial Management Association, the World Finance Conference 2016 as well as of the $27^{\text {th }}$ European Conference on Operational Research for helpful comments and discussions. We like to thank two anonymous referees, Goetz Greve, the Claussen-Simon Foundation, and the Association of Friends \& Sponsors of the HSBA.

\section{References}

[1] D. Miles, J. Yang, G. Marcheggiano, Optimal Bank Capital, The Economic Journal, vol. 123, (2012), pp. 1-37.

[2] European Banking Authority, Guidelines on common procedures and methodologies for the supervisory review and evaluation process (SREP), EBA/GL/2014/13, (2014).

[3] R. Ayadi, W. De Groen, I. Sassi, W. Mathlouthi, H. Rey, O. Aubry, Banking Business Models Monitor 2015 Europe, Alphonse and Doriméne Desjardins International Institute for Cooperatives and International Research Centre on Cooperative Finance, Working Paper, (2015).

[4] F. Mergaerts, R. Vander Vennet, Business models and bank performance: A longterm perspective, Journal of Financial Stability, vol. 22, (2016), pp. 57-75.

[5] R. Roengpitya, N. Tarashev, K. Tsatsaronis, Bank business models, BIS Quarterly Review, December, (2014), pp. 55-65.

[6] M. Koehler, Which banks are more risky? The impact of business models on bank stability, Journal of Financial Stability, vol. 16, (2015), pp. 195-212.

[7] A. Admati, P. DeMarzo, M. Hellwig, P. Pfleiderer, Fallacies, Irrelevant Facts, and Myths in the Discussion of Capital Regulation: Why Bank Equity is Not Socially Expensive, Rock Center for Corporate Governance - Working Paper Series, no. 161, (2013).

[8] F. Modigliani, M. Miller, The Cost of Capital, Corporation Finance and the Theory of Investment, The American Economic Review, vol. 48, no. 3, (1958), pp. 261-297.

[9] M. Miller, Merton H., Do the M \& M propositions apply to banks?, Journal of Banking and Finance, vol. 19, (1995), pp. 483-489.

[10] P. Pfleiderer, On the Relevancy of Modigliani and Miller to Banking: A Parable and Some Observations (Revised), Stanford Graduate School of Business, Working Paper, (2015). 
[11] European Central Bank, Common Equity Capital, Banks' Riskiness and Required Return on Equity, Financial Stability Report, December, (2011), pp. 125-131.

[12] G. Junge, P. Kugler, Quantifying the impact of higher capital requirements on the Swiss economy, WWZ Discussion Paper, (2012).

[13] O. Toader, Estimating the Impact of Higher Capital Requirements on the Cost of Equity: An Empirical Study of European Banks, International Economics and Economic Policy, vol. 12, no. 3, (2015), pp. 411-436.

[14] B. Clark, J. Jones, D. Malmquist, Leverage and the Weighted-Average Cost of Capital for U.S. Banks, Working Paper, (2015).

[15] W. Cline, Testing the Modigliani-Miller Theorem of Capital Structure Irrelevance for Banks, Peterson Institute for International Economics, Working Paper Series, no. 8, (2015).

[16] Bankscope-Database, Bureau van Dijk Electronic Publishing, Hanauer Landstraße 175-179, 60314 Frankfurt am Main, Germany, (2015).

[17] Deutsche Bundesbank, Structural developments in the German banking sector, Deutsche Bundesbank, Monthly Report, vol. 67, no. 4, April, (2015), pp. 35-60.

[18] J. Hull, Risk Management and Financial Institutions, Fourth edition, John Wiley \& Sons, New Jersey, 2015.

[19] T. Heidorn, S. Rupprecht, Einführung in das Kapitalstrukturmanagement bei Banken, Frankfurt School, Working Paper Series, no. 121, (2009).

[20] Basel Committee on Banking Supervision, Basel III: A global regulatory framework for more resilient banks and banking systems, December 2010 (rev June 2011), Bank for International Settlements, (2011).

[21] Basel Committee on Banking Supervision, Calibrating regulatory minimum capital requirements and capital buffers: a top-down approach, Bank for International Settlements, (2011).

[22] Deutsche Bundesbank, Banking statistics June 2015, Statistical Supplements to the Monthly Report, Deutsche Bundesbank, Statistical Supplement, June, (2015).

[23] E. Fama, K. French, The Cross-Section of Expected Stock Returns, The Journal of Finance, vol. 47, no. 2, (1992), pp. 427-465.

[24] A. Damodaran, Equity Risk Premiums (ERP): Determinants, Estimation and Implications - The 2013 Edition, Stern School of Business, (2013).

[25] J. Wooldridge, Econometric Analysis of Cross-Section and Panel Data, MIT Press, Massachusetts, 2002.

[26] J. Wooldridge, Introductory Econometrics, A Modern Approach, Fourth international student edition, Cengage Learning Emea, Hampshire, 2009.

[27] M. Arellano, Computing robust standard errors for within group estimators, Oxford Bulletin of Economics and Statistics, vol. 49, no. 4, (1987), pp. 431-434.

[28] J. Driscoll, A. Kraay, Consistent Covariance Matrix Estimation with Spatially Dependent Panel Data, Review of Economics and Statistics, vol. 80, no. 4, (1998), pp. 549-560.

[29] Y. Croissant, G. Millo, Panel Data Econometrics in R: The plm Package, Journal of Statistical Software, vol. 27, no. 2, (2008), pp. 1-43.

[30] K. Ueda, B. Weder di Mauro, Quantifying structural subsidy values for systemically important financial institutions, Journal of Banking and Finance, vol. 37, (2013), pp. 3820-3842.

[31] Deutsche Bundesbank, Time Series BBK01.WT3404 for a five year German Treasury bond, Deutsche Bundesbank, (2015). 
http://www.bundesbank.de/Navigation/DE/Statistiken/Zeitreihen_Datenbanken/Mak rooekonomische_Zeitreihen/its_details_value_node.html?tsId=BBK01.WT3404\&da teSelect $=2013$

[32] R. Ayadi, E. Arbak, W. De Groen, Business Models in European Banking: A pre- and post-crisis screening, Centre for European Policy Studies, Working Paper, (2011). 


\section{Appendix}

Appendix I. Comparative studies.

\begin{tabular}{|c|c|c|c|c|c|c|}
\hline & $\begin{array}{c}\text { Miles et al. } \\
{[1]}\end{array}$ & $\begin{array}{c}\text { ECB } \\
{[11]} \\
\end{array}$ & $\begin{array}{c}\text { Junge et al. } \\
{[12]}\end{array}$ & $\begin{array}{c}\text { Toader } \\
{[13]}\end{array}$ & $\begin{array}{c}\text { Clark et al. } \\
{[14]}\end{array}$ & $\begin{array}{c}\text { Cline } \\
{[15]}\end{array}$ \\
\hline Location & UK & $\begin{array}{c}\text { International } \\
\text { G-SIBs } \\
\end{array}$ & Swiss & Europe & USA & USA \\
\hline Sample & 6 banks & 54 banks & 5 banks & 85 banks & 200 banks & 51 banks \\
\hline Timeframe & $6 / 1997-6 / 2010$ & $6 / 1995-6 / 2011$ & $\begin{array}{c}6 / 1999- \\
6 / 2010 \\
\end{array}$ & $1997-2012$ & $\begin{array}{c}3 / 1996- \\
12 / 2012 \\
\end{array}$ & $2001-2013$ \\
\hline Data origin & $\mathrm{n} / \mathrm{a}$ & Bloomberg & $\begin{array}{c}\text { Datastream, } \\
\text { FINMA }\end{array}$ & Bankscope & $\begin{array}{c}\text { Chicago FED, } \\
\text { CRSP }\end{array}$ & $\begin{array}{c}\text { Bloomberg, } \\
\text { bank's websites }\end{array}$ \\
\hline Regression & $\beta=X^{\prime} b+(\alpha+\mu)$ & $\begin{array}{l}\beta \\
=a+b \cdot C R+ \\
\quad X+d+u\end{array}$ & $\begin{array}{c}\log (\beta)= \\
a+b \cdot \log (l r) \\
+\quad \\
\eta+\delta+\varepsilon\end{array}$ & $\beta=\alpha+X^{\prime} C R+u$ & $\begin{array}{l}\beta \\
=b+x+z+\mu\end{array}$ & $\begin{array}{l}N I / E \\
=a+z+d\end{array}$ \\
\hline Variables $^{14}$ & $\begin{array}{l}\beta-\text { Equity beta } \\
X-\text { Lagged leverage }+ \\
\text { year dummies } \\
b-\text { Control var. } \\
\alpha-\text { Bank specific effect } \\
\mu-\text { Error term }\end{array}$ & $\begin{array}{l}\beta-\text { Equity beta } \\
a-\text { Fixed } \\
\text { effects } \\
C R-\text { Lagged } \\
\text { capital ratio } \\
X-\text { Control var. } \\
d-\text { Time fixed } \\
\text { effects } \\
u-\text { Error term }\end{array}$ & $\begin{array}{l}\beta-\text { Equity } \\
\text { beta } \\
a-\text { Constant } \\
l r-\text { Leverage } \\
\eta-\text { Bank } \\
\text { specific effect } \\
\delta-\text { Time } \\
\text { specific effect } \\
\varepsilon-\text { Error term }\end{array}$ & $\begin{array}{l}\beta-\text { Equity beta } \\
C R-\text { Capital ratio- } \\
\text { RWA } \\
X-\text { Bank specific } \\
\text { control variable and } \\
\text { time dummy } \\
u-\text { Error term }\end{array}$ & $\begin{array}{l}\beta-\text { Equity beta } \\
b-\text { Lagged } \\
\text { leverage } \\
x-\text { Bank- } \\
\text { specific } \\
\text { variables } \\
z-\text { Year dummy } \\
\text { or macro. } \\
\text { variable } \\
\mu-\text { Error term } \\
\end{array}$ & $\begin{array}{l}N I / E-\text { Net } \\
\text { income to equity } \\
\text { ratio } \\
a-\text { Constant } \\
z-\text { ratio of debt } \\
\text { to equity } \\
d-\text { dummy } \\
\text { variable }\end{array}$ \\
\hline
\end{tabular}

${ }^{14}$ Variables: Leverage $=$ Total assets $/$ Tier 1 capital; Capital ratio $(\mathrm{CR})=$ Tier 1 capital $/$ Total assets; Capital ratio-RWA = Tier 1 capital $/$ RWA. 


\begin{tabular}{|c|c|c|c|c|c|c|}
\hline $\begin{array}{l}\text { Control } \\
\text { Variables }^{15}\end{array}$ & $\begin{array}{l}\text { - LLRR } \\
\text { - LAR } \\
\text { - ROA }\end{array}$ & $\begin{array}{l}\text { - ROA } \\
\text { - Size } \\
\text { - RWA }\end{array}$ & $\mathrm{n} / \mathrm{a}$ & $\begin{array}{l}\text { - LLRR } \\
\text { - LAR } \\
\text { - ROA + Size }\end{array}$ & $\begin{array}{l}\text { - LLRR } \\
\text { - LAR } \\
\text { - ROA }\end{array}$ & $\mathrm{n} / \mathrm{a}$ \\
\hline Coefficient & $\begin{array}{l}\text { OLS: } 0.025 * * * \\
\mathrm{RE}: 0.025 * * * \\
\mathrm{FE}: 0.031 * * *\end{array}$ & $\begin{array}{l}\text { No control var.: } \\
-0.045^{* * *} \\
\text { With control } \\
\text { var.: }-0.079 * * *\end{array}$ & $\mathrm{n} / \mathrm{a}$ & $\begin{array}{l}\text { OLS: }-0.022 * * * \\
\text { RE: }-0.0257 * * * \\
\text { FE: }-0.0259 * * *\end{array}$ & $\begin{array}{l}\text { FE Basic: } \\
0.064 * * * \\
\text { FE Extended: } \\
0.062 * * *\end{array}$ & $\begin{array}{l}\text { OLS: } 0.636 * * * \\
\text { RE: } \mathrm{n} / \mathrm{a} \\
\text { FE: } 0.708\end{array}$ \\
\hline $\begin{array}{l}\text { Coefficient Log- } \\
\text { Model }\end{array}$ & $\begin{array}{l}\text { OLS: } 0.602 * * * \\
\text { RE: } 0.602 * * * \\
\text { FE: } 0.692 * * *\end{array}$ & $\mathrm{n} / \mathrm{a}$ & $\begin{array}{l}\text { OLS: } \mathrm{n} / \mathrm{a} \\
\text { RE: } 0.763 * * \\
\text { FE: } 0.554 * *\end{array}$ & $\begin{array}{l}\text { OLS: }-0.251 * * * \\
\text { RE: }-0.418 * * * \\
\text { FE: }-0.426 * * *\end{array}$ & $\begin{array}{l}\text { OLS: } \mathrm{n} / \mathrm{a} \\
\mathrm{RE}: \mathrm{n} / \mathrm{a} \\
\mathrm{FE}: 0.902 * * *\end{array}$ & $\mathrm{n} / \mathrm{a}$ \\
\hline Observations & $\mathrm{n} / \mathrm{a}$ & $652-1,372$ & $\mathrm{n} / \mathrm{a}$ & 721 & 10,577 & 579 \\
\hline R-squared & $0.634-0.671$ & $0.360-0.530$ & $0.307-0.849$ & $0.025-0.099$ & $0.395-0.486$ & 0.268 \\
\hline $\begin{array}{l}\text { Specific model } \\
\text { characteristics }\end{array}$ & $\begin{array}{l}\text { Control variables were } \\
\text { dropped because of no } \\
\text { significance }\end{array}$ & $\begin{array}{l}\text { - Log-RWA } \\
\text { - Log-Total } \\
\text { assets (Size) }\end{array}$ & $\mathrm{n} / \mathrm{a}$ & $\begin{array}{l}\text { - Log-CR-RWA } \\
\text { - Log-Total assets } \\
\text { (Size) } \\
\text { - 'Expected' ROE }\end{array}$ & $\begin{array}{l}\text { - Pre/post crisis } \\
\text { - Size } 200 \text { bn. } \$ \\
\text { - Leverage } \leq \\
66.67\end{array}$ & $\begin{array}{l}\text { - Actual returns } \\
\text { - Swap negative } \\
\text { returns }\end{array}$ \\
\hline M/M Offset & $45 \%-90 \%$ & $41 \%-73 \%$ & $36 \%-55 \%$ & $42 \%$ & $41 \%-100 \%$ & $60 \%$ \\
\hline
\end{tabular}

${ }^{15}$ Control Variables: Loan loss reserve ratio $($ LLRR $)=$ Total loan-loss reserves / Assets; Liquidity (asset) ratio $($ LAR $)=($ Cash/ deposits of depository institution + Available-for-Sale securities) $/($ Total liabilities - equity); Return on assets $($ ROA $)=$ Net income $/$ Total assets; Size $=$ logarithm of total assets. 


\section{Appendix II. Yearly observations.}

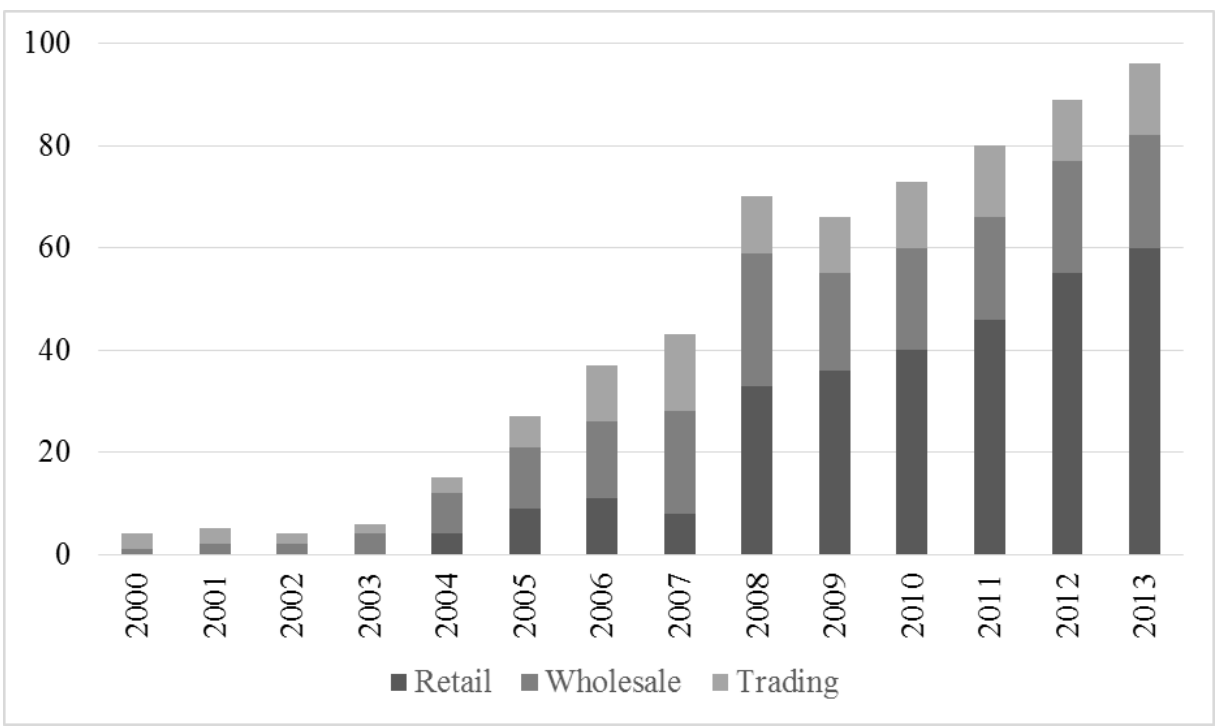

Figure 2: Yearly Observations.

\section{Appendix III. Descriptive statistics for utilized variables.}

Table 9: Dependent Variable - Net Return on Tier 1 Capital.

\begin{tabular}{lcccccc}
\hline \multicolumn{1}{c}{ Sample } & Obs. & Mean & Min. & Max. & Median & Std. Dev. \\
\hline & & & & & & \\
All banks & 615 & 0.085 & -0.447 & 0.460 & 0.074 & 0.114 \\
Retail banks & 302 & 0.091 & -0.356 & 0.460 & 0.071 & 0.094 \\
Wholesale banks & 193 & 0.071 & -0.447 & 0.411 & 0.062 & 0.130 \\
Trading banks & 120 & 0.094 & -0.378 & 0.362 & 0.097 & 0.131 \\
& & & & & & \\
\hline
\end{tabular}

Notes: Calculated as net income divided by Tier 1 capital.

Table 10: Independent Variable - Leverage.

\begin{tabular}{lcccccc}
\hline \multicolumn{1}{c}{ Sample } & Obs. & Mean & Min. & Max. & Median & Std. Dev. \\
& & & & & & \\
All banks & 615 & 26.19 & 7.49 & 149.78 & 22.58 & 14.87 \\
Retail banks & 302 & 18.65 & 7.49 & 69.90 & 17.63 & 7.43 \\
Wholesale banks & 193 & 29.59 & 8.38 & 76.29 & 28.02 & 10.46 \\
Trading banks & 120 & 39.69 & 10.18 & 149.78 & 36.75 & 21.86 \\
\end{tabular}

Notes: Calculated as balance sheet total divided by Tier 1 capital.

Table 11: Independent Variable - Return on Assets.

\begin{tabular}{lcccccc}
\hline \multicolumn{1}{c}{ Sample } & Obs. & Mean & Min. & Max. & Median & Std. Dev. \\
& & & & & & \\
All banks & 611 & 0.004 & -0.018 & 0.025 & 0.004 & 0.005 \\
Retail banks & 298 & 0.005 & -0.018 & 0.025 & 0.004 & 0.005 \\
Wholesale banks & 193 & 0.003 & -0.015 & 0.017 & 0.002 & 0.005 \\
Trading banks & 120 & 0.003 & -0.009 & 0.014 & 0.003 & 0.004 \\
\end{tabular}

Notes: Calculated as net income divided by balance sheet total. 
Table 12: Independent Variable - Liquid Asset Ratio.

\begin{tabular}{lcccccc}
\hline \multicolumn{1}{c}{ Sample } & Obs. & Mean & Min. & Max. & Median & Std. Dev. \\
\hline & & & & & & \\
All banks & 610 & 0.254 & 0.002 & 7.467 & 0.185 & 0.347 \\
Retail banks & 297 & 0.166 & 0.002 & 7.467 & 0.136 & 0.434 \\
Wholesale banks & 193 & 0.279 & 0.020 & 0.833 & 0.241 & 0.176 \\
Trading banks & 120 & 0.432 & 0.133 & 1.031 & 0.387 & 0.209 \\
& & & & & & \\
\hline
\end{tabular}

Notes: Calculated as liquid assets divided by balance sheet total minus equity.

Appendix IV. Fixed effects regression models including control variables.

Table 13: All Banks.

\begin{tabular}{|c|c|c|c|c|c|c|}
\hline FE & (1) & (2) & (3) & (4) & (5) & (6) \\
\hline Leverage & $\begin{array}{c}0.040^{\prime} \\
(0.022)\end{array}$ & $\begin{array}{c}0.003 \\
(0.025)\end{array}$ & $\begin{array}{c}0.064 * * * \\
(0.013)\end{array}$ & $\begin{array}{c}0.066 * * * \\
(0.013)\end{array}$ & $\begin{array}{c}0.067 * * * \\
(0.013)\end{array}$ & $\begin{array}{c}0.064 * * * \\
(0.022)\end{array}$ \\
\hline ROA & & & $\begin{array}{c}23.951 * * * \\
(0.656)\end{array}$ & $\begin{array}{c}24.011 * * * \\
(0.654)\end{array}$ & $\begin{array}{c}24.000 * * * \\
(0.656)\end{array}$ & $\begin{array}{c}25.296 * * * \\
(0.806)\end{array}$ \\
\hline LAR & & & & $\begin{array}{l}0.014 * \\
(0.006)\end{array}$ & $\begin{array}{c}0.013 * * \\
(0.006)\end{array}$ & $\begin{array}{c}0.003 \\
(0.012)\end{array}$ \\
\hline Total Assets & & & & & $\begin{array}{l}-0.003 \\
(0.015)\end{array}$ & $\begin{array}{l}-0.002 \\
(0.019)\end{array}$ \\
\hline LLRR & & & & & & $\begin{array}{l}-0.007 \\
(0.005)\end{array}$ \\
\hline Year Effects & No & Yes & Yes & Yes & Yes & Yes \\
\hline Observations & 615 & 615 & 611 & 610 & 610 & 421 \\
\hline $\mathrm{R}^{2}$ & 0.007 & 0.311 & 0.818 & 0.820 & 0.820 & 0.863 \\
\hline Adjusted $\mathrm{R}^{2}$ & 0.005 & 0.245 & 0.643 & 0.642 & 0.641 & 0.615 \\
\hline F Statistic & $\begin{array}{l}3.289 *(\mathrm{df} \\
135.984 * * \\
300)\end{array}$ & $\begin{array}{l}; 497) \\
\mathrm{f}=16 ;\end{array}$ & $\begin{array}{l}92 * * *(\mathrm{df} \\
127.734 *\end{array}$ & $\begin{array}{l}14 ; 484) 14 \\
(\mathrm{df}=17 ; 4\end{array}$ & $\begin{array}{l}3.714 * * * \\
\text { 7) } 104.863\end{array}$ & $\begin{array}{l}=15 ; 480) \\
*(\mathrm{df}=18\end{array}$ \\
\hline
\end{tabular}

Notes: The dependent variable is the log of the net return on Tier 1 capital. The independent variables are logarithmized. ROA is the return on assets. LAR is the liquid asset ratio. Total Assets is the balance sheet total. LLRR is the loan loss reserve ratio. Calculations without standard robust errors. Standard errors in parentheses.

Level of significance: $* * * p<0.001, * * p<0.01, * p<0.05,{ }^{\prime} p<0.10$. 
Table 14: Retail Banks.

\begin{tabular}{|c|c|c|c|c|c|c|}
\hline FE & (1) & (2) & (3) & (4) & (5) & (6) \\
\hline Leverage & $\begin{array}{c}0.041 \\
(0.026)\end{array}$ & $\begin{array}{l}-0.015 \\
(0.030)\end{array}$ & $\begin{array}{c}0.075^{* * *} \\
(0.014)\end{array}$ & $\begin{array}{c}0.076 * * * \\
(0.014)\end{array}$ & $\begin{array}{c}0.073 * * * \\
(0.014)\end{array}$ & $\begin{array}{c}0.036 \\
(0.028)\end{array}$ \\
\hline ROA & & & $\begin{array}{c}18.290 * * * * \\
(0.639)\end{array}$ & $\begin{array}{c}18.401 * * * * \\
(0.645)\end{array}$ & $\begin{array}{c}18.458 * * * \\
(0.643)\end{array}$ & $\begin{array}{c}20.321 * * * \\
(1.181)\end{array}$ \\
\hline LAR & & & & $\begin{array}{c}0.005 \\
(0.004)\end{array}$ & $\begin{array}{c}0.007 \\
(0.004)\end{array}$ & $\begin{array}{c}0.007 \\
(0.016)\end{array}$ \\
\hline Total Assets & & & & & $\begin{array}{l}0.026^{*} \\
(0.014)\end{array}$ & $\begin{array}{c}0.039 \\
(0.025)\end{array}$ \\
\hline LLRR & & & & & & $\begin{array}{c}0.017 \\
(0.019)\end{array}$ \\
\hline Year Effects & No & Yes & Yes & Yes & Yes & Yes \\
\hline Observations & 302 & 302 & 298 & 297 & 297 & 160 \\
\hline $\mathrm{R}^{2}$ & 0.010 & 0.279 & 0.848 & 0.849 & 0.851 & 0.884 \\
\hline Adjusted $\mathrm{R}^{2}$ & 0.008 & 0.208 & 0.629 & 0.626 & 0.625 & 0.492 \\
\hline F Statistic & $\begin{array}{l}2.407(\mathrm{df} \\
=12 ; 219\end{array}$ & $\begin{array}{l}\text {;234) } 8 . \\
5.030^{* * * *}\end{array}$ & $\begin{array}{l}* *(\mathrm{df}=10 \\
=13 ; 218)\end{array}$ & $\begin{array}{l}\text { 5) } 112.023 * \\
80 * * *(\mathrm{df}=\end{array}$ & $\begin{array}{l}\mathrm{df}=11 ; 221 \\
89)\end{array}$ & $2.703 * * *(d)$ \\
\hline
\end{tabular}

Notes: The dependent variable is the log of the return on Tier 1 capital after taxes. The independent variables are logarithmized. ROA is the return on assets. LAR is the liquid asset ratio. Total Assets are the balance sheet total. LLRR is the loan loss reserve ratio. Calculations without standard robust errors. Standard errors in parentheses.

Level of significance: $* * * p<0.001, * * p<0.01, * p<0.05,{ }^{\prime} p<0.10$.

Table 15: Combined Wholesale and Trading Banks.

\begin{tabular}{|c|c|c|c|c|c|c|}
\hline FE & (1) & (2) & (3) & (4) & (5) & (6) \\
\hline \multirow[t]{2}{*}{ Leverage } & $\begin{array}{c}0.02 \\
7\end{array}$ & 0.039 & $0.045^{* *}$ & $0.047^{*}$ & $0.054 * * *$ & $0.062 * *$ \\
\hline & $\begin{array}{c}(0.03 \\
3)\end{array}$ & $(0.039)$ & $(0.019)$ & $(0.019)$ & $(0.020)$ & $(0.028)$ \\
\hline ROA & & & $\begin{array}{c}29.400 * * * \\
(1.043)\end{array}$ & $\begin{array}{c}29.349 * * * \\
(1.045)\end{array}$ & $\begin{array}{c}29.372 * * * \\
(1.042)\end{array}$ & $\begin{array}{c}28.518 * * * * \\
(1.086)\end{array}$ \\
\hline LAR & & & & $\begin{array}{c}0.015 \\
(0.015)\end{array}$ & $\begin{array}{c}0.013 \\
(0.015)\end{array}$ & $\begin{array}{c}0.015 \\
(0.016)\end{array}$ \\
\hline Total Assets & & & & & $\begin{array}{l}-0.036 \\
(0.025)\end{array}$ & $\begin{array}{l}-0.045 \\
(0.029)\end{array}$ \\
\hline LLRR & & & & & & $\begin{array}{l}-0.006 \\
(0.005)\end{array}$ \\
\hline Year Effects & No & Yes & Yes & Yes & Yes & Yes \\
\hline Observations & 313 & 313 & 313 & 313 & 313 & 261 \\
\hline $\mathrm{R}^{2}$ & $\begin{array}{c}0.00 \\
3\end{array}$ & 0.337 & 0.848 & 0.849 & 0.850 & 0.880 \\
\hline Adjusted $\mathrm{R}^{2}$ & $\begin{array}{c}0.00 \\
2\end{array}$ & 0.255 & 0.640 & 0.637 & 0.636 & 0.634 \\
\hline F Statistic & $\begin{array}{l}0.658 \\
16 ; 23\end{array}$ & $\begin{array}{l}=1 ; 250 \\
8.088^{* *}\end{array}$ & $\begin{array}{l}521 * * *(\mathrm{df}= \\
\mathrm{f}=17 ; 234)\end{array}$ & $\begin{array}{l}\text { 237) } 87.908 \\
4 * * *(\mathrm{df}=1\end{array}$ & $\begin{array}{l}\mathrm{df}=15 ; 236 \\
88)\end{array}$ & $491 * * *(\mathrm{df}=$ \\
\hline
\end{tabular}

Notes: The dependent variable is the log of the return on Tier 1 capital after taxes. The independent variables are logarithmized. ROA is the return on assets. LAR is the liquid asset ratio. Total Assets are the balance sheet total. LLRR is the loan loss reserve ratio. Calculations without standard robust errors. Standard errors in parentheses.

Level of significance: $* * * p<0.001, * * p<0.01, * p<0.05,{ }^{\prime} p<0.10$. 